\title{
The storm surge recorded in a thin section
}

\author{
Aleksandra Vierek \\ The Jerzy Kukuczka Academy of Physical Education in Katowice, Mikołowska 72A st. \\ E-mail address: a.vierek@awf.katowice.pl
}

\begin{abstract}
Keywords: tempestites; carbonate platform; microfacies analysis; Upper Devonian, Holy Cross Mountains
\end{abstract}

ABSTRACT. Limestone and sandstone beds deposited by storms are called tempestites, and exhibit much variation in thickness, grain size and internal structures, depending on the proximity and on the intensity of the storm waves. In this paper, diagnostic features of storm beds observed in thin sections, was presented.

Characteristic features are investigated on the basis of detailed study in the Upper Devonian carbonates in the western part of the Holy Cross Mountains (Poland).

\section{INTRODUCTION}

The shallow-water setting near shoreline is characterized by sediments formed by wave, current and tides. The particular importance is intense storm events, which reworked carbonate or sandstone sediments in the shallow and deeper waters (up to storm wave base ${ }^{1}$ ).

High-energy storms generate waves and currents that affect sea bottoms, stir up sediment and create characteristic structures and textures of layers. Carbonate and sandstone beds deposited by storms are called tempestites. This term introduced by Gilbert Kelling, but in the sedimentological literature was used in the first by Ager'a in 1974 year [1].

Tempestites are a class of event deposits. Eventstones are the results of short-term processes that produce characteristic sedimentary signatures. Tempestite beds exhibit great variation in thickness, grain size and internal structures, depending mostly on the proximality-distality trends and the intensity of the storm [2].

In the first, high-energy stage of storm, decrease storm wave-base. The proximal tempestites are coarse-grained, thick-bedded and bioclasts dominated. The proximal tempestites are also distinguished by erosional and sharp bottom contact with channels and scours filled with micritic clasts, crinoid and brachiopod skeletal grains, cutting into fine-grained limestones. Storm waves and currents deposit layers exhibiting characteristic undulated bedding (hummocky cross-stratification, $=H C S$ ). This structures shows gently curved, low-angle cross lamination and laminae with convexupwards (hummock) and concave-upwards (swale) developed curvatures. At quieter and greater water depths, HCS becomes less distinct and is replaced by parallel laminations that may indicate unidirectional flows.

In deeper depositional environments and/or low-energy conditions formed distal tempestites. These beds tend to become thinner, finer, rarer and better preserved [4]; [5]. Bioturbation and burrowing are commonly strong in the upper part of storm, distal beds.

Depending on the morphology of the shallow sea bottom characteristics features of tempestites may be more or less clear. In a shallow basin, on an environment of mildly inclined carbonate ramps the tempestites are characterized by the complete development of diagnostic sedimentary structures and a distinct transition from the high-energy proximal tempestites to the low-energy, distal deposition. The rock record is much more distinctive than on the isolated carbonate platform with a steep slope, where the disturbance of the proximal-distal trend is frequently observed (i.e. intense amalgamation and cannibalism, fast thinning-out of beds and the related absence in many places of the distinctive proximal-distal trend)

\footnotetext{
${ }^{1}$ The depth of the storm wave-base varies strongly: about $50 \mathrm{~m}$ down to $250 \mathrm{~m}$ in shelf seas, and about 20 to $30 \mathrm{~m}$ in epicontinental seas [3].
} 
The present study is a detailed microfacies analysis of the storm beds. Three outcrops were examined in different parts of the Holy Cross Mountains (HCM). The limestone classification and nomenclature developed by Folk [6] and Wright [7] was applied tops the microscopic analysis.

\section{REGIONAL PALAEOGEOGRAPHIC SETTING}

The palaeogeographical pattern of the Givetian to Frasnian in the HCM in Poland is characterized by two distinct tectonic regions [8]: the northern palaeolow in the Łysogóry region and the southern palaeohigh in the Kielce region. Later research identified a separate Kostomłoty transitional zone between the shallow-water Kielce region and the broadly-defined Łysogóry basin deposits [9]. In the Kielce area, the biostrome-colonized platform, characterizing the Givetian, evolved into a stromatoporoid-coral reef-rimmed platform complex (the Dyminy reef complex of Racki [9]) as a result of the Early and Middle Frasnian transgression. The Dyminy reef developed over the northern marginal zone of the extensive Kielce carbonate platform. The Upper Devonian carbonate platform is a reef-rimmed isolated platform with a relatively steep margin akin to the rimmed platform base-of-slope aprons [4]. On such an isolated carbonate platform, as modern Bahama Banks, the effects of storms are concentrated at the platform margin and storm processes are particularly important in controlling the depositional facies along this margin. In addition, proximality-distality trends is often unsettled because quick passage from shallow to deeper-water environments. Higher and steeper slopes provide greater offshore-directed driving force for sediment-rich, storm-generated flows (gravity flows and/or turbidity currents).

Coral growing in these places partly isolate platform water from the waters of the open sea and create a diverse environment. Varied limestone deposition and the formation of carbonate shoals of widely differing textures and sedimentary structures are the results.

Late Devonian coarse-grained carbonate deposits at several places in the HCM (Wietrznia, Kostomłoty-Mogiłki, Górno-field quarries) were studied for possible storm depositional systems, as it must be assumed that the investigated area was strongly affected by tropical hurricanes generated in the open ocean North of Gondwana. The palaeoclimate conditions, with average temperatures of about $28^{\circ} \mathrm{C}$, and the palaeogeographical location of the HCMs region during the Late Devonian between $5^{0}-10^{0} \mathrm{~S}$ favoured the influence of tropical hurricanes on the sedimentary environment and deposition of carbonate rocks [10]. This assumption appears consistent with diagnostic features of tempestites (event beds). Sedimentary structures and textures, that indicate so are, among other evidence, erosional bases with sole marks, graded units, intra- and bioclasts, different lamination and burrowing at the tops of layers [4]; [5]; [11].

\section{STORM DEPOSITS IN MICROFACIES ANALYSIS}

Transport and redeposition by storm wave produce millimeter- to meter-thick storm layers, contribute to the formation of lag deposits, and change the distribution patterns of benthic organisms. In thin beds, microfacies analysis is particularly important, and shows much information about transport mechanism and origin of the grained material. 


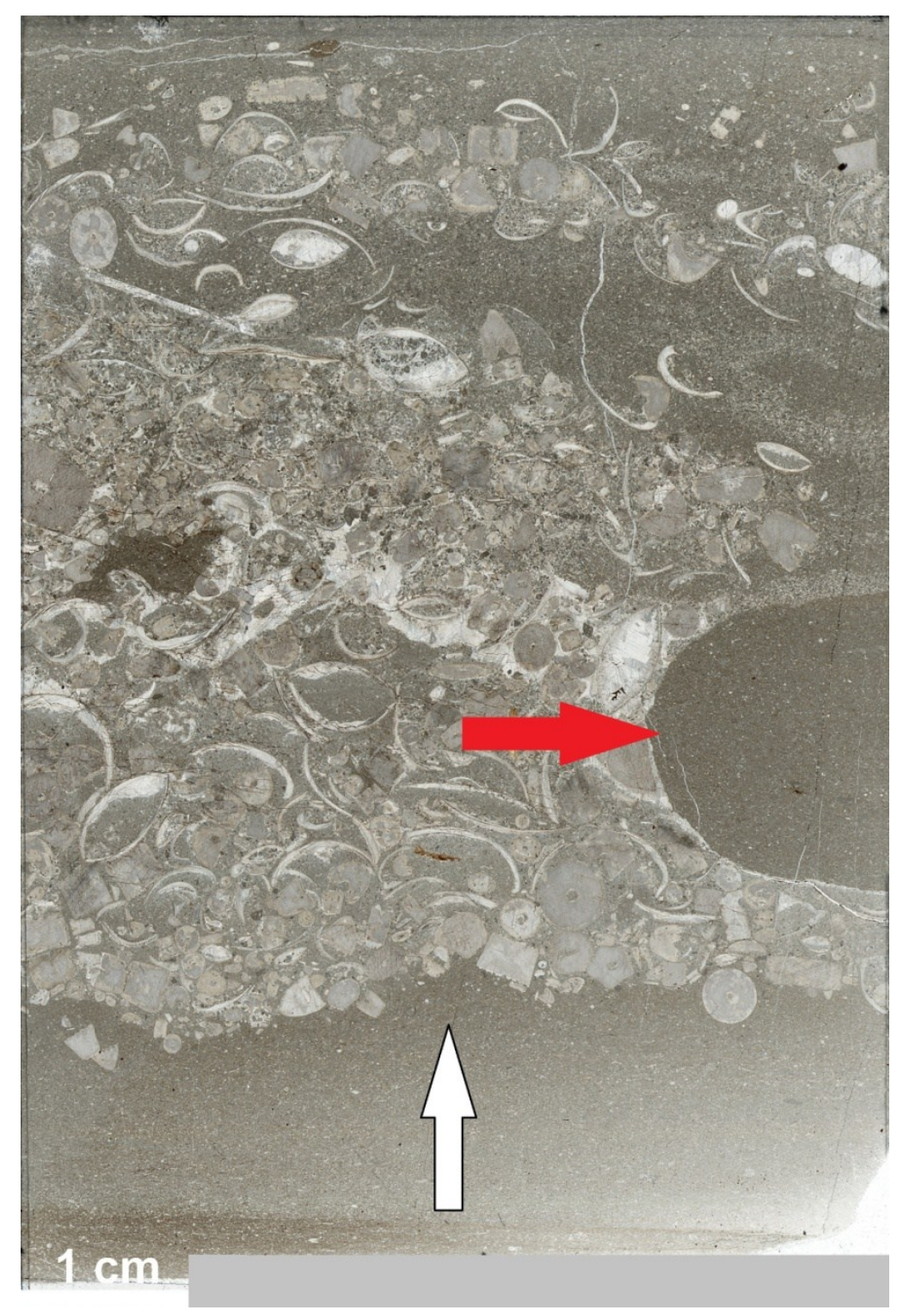

Fot. 1. Biopelintraspar(rud)ites: the coarse-grained limestones with densely packed and well-sorted brachiopod valves and crinoids debris. Note the relatively sharp contact between the micritic and coarsegrained lithofacies (white arrow). Red arrow shows micritic intraclast. The Wietrznia quarry, thin section 70. Fot. A. Vierek.

Tempestite beds are intercalated in marly, shale or micritic limestones and shows distinct differences in grain size of tempestites and of under- and overlying beds (who are normal quiet sedimentation). In addition, thickness often differs markedly from that of underlying and overlying beds (Fot. 1). The other diagnostic features are the erosional and sharp bottom contact with channels and scours filled with micritic clasts, crinoid and brachiopod skeletal grains, cutting into fine-grained limestones. Locally, in the coarse-grained layers, the bases are erosional and vary in character, from flat, gently wavy to the distinctly U- and V-shaped depressions (Fot. 1-3). The infilling material is unsorted and heterogeneous. 


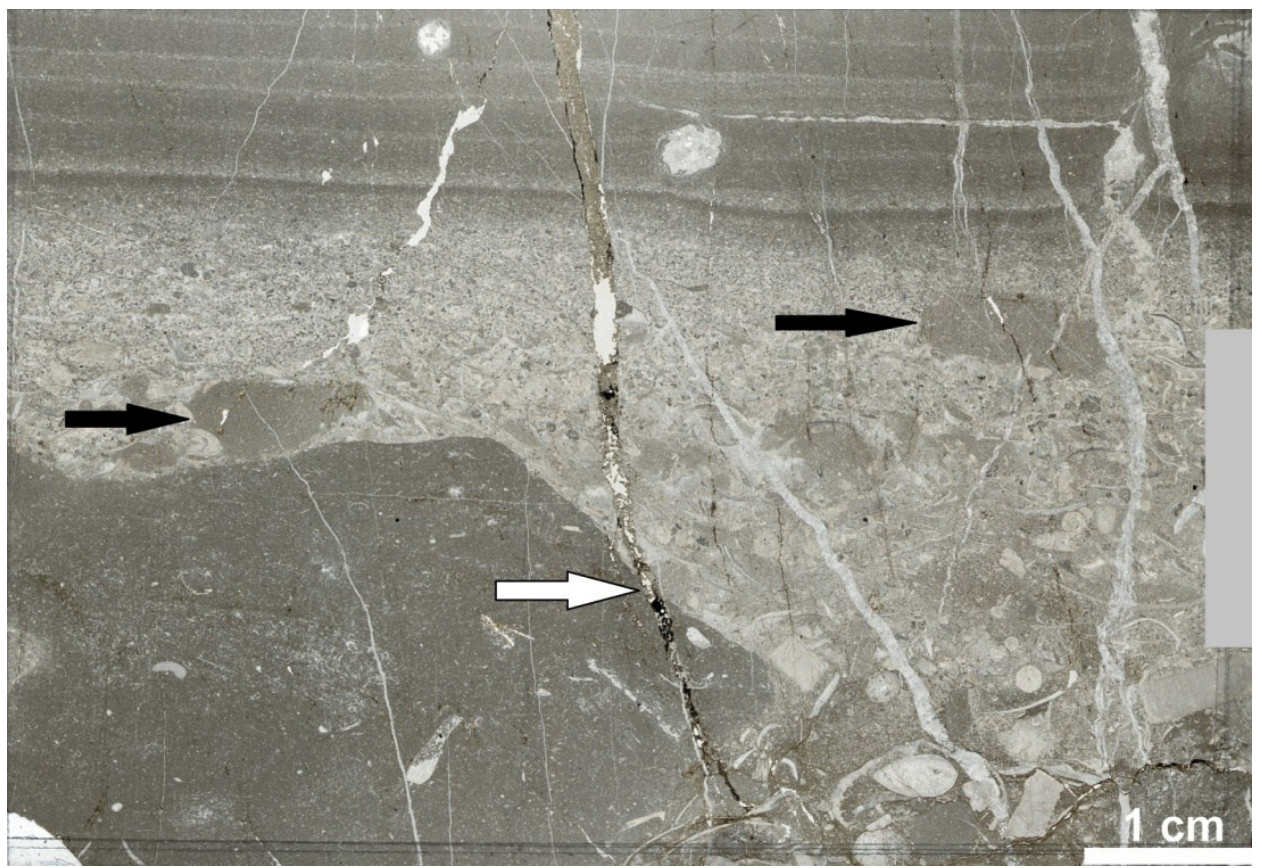

Fot. 2. Pelbiomicrosparites: photomicrograph showing erosional relief with distinctly v-shaped depression (white arrow) at the base of a tempestite layer (black arrows - micritic intraclasts). Note distinct segregation into coarse-grained (lower) and fine laminated (upper) members, and burrows beneath the layer base. The Wietrznia quarry, thin section 13 . Fot. A. Vierek.

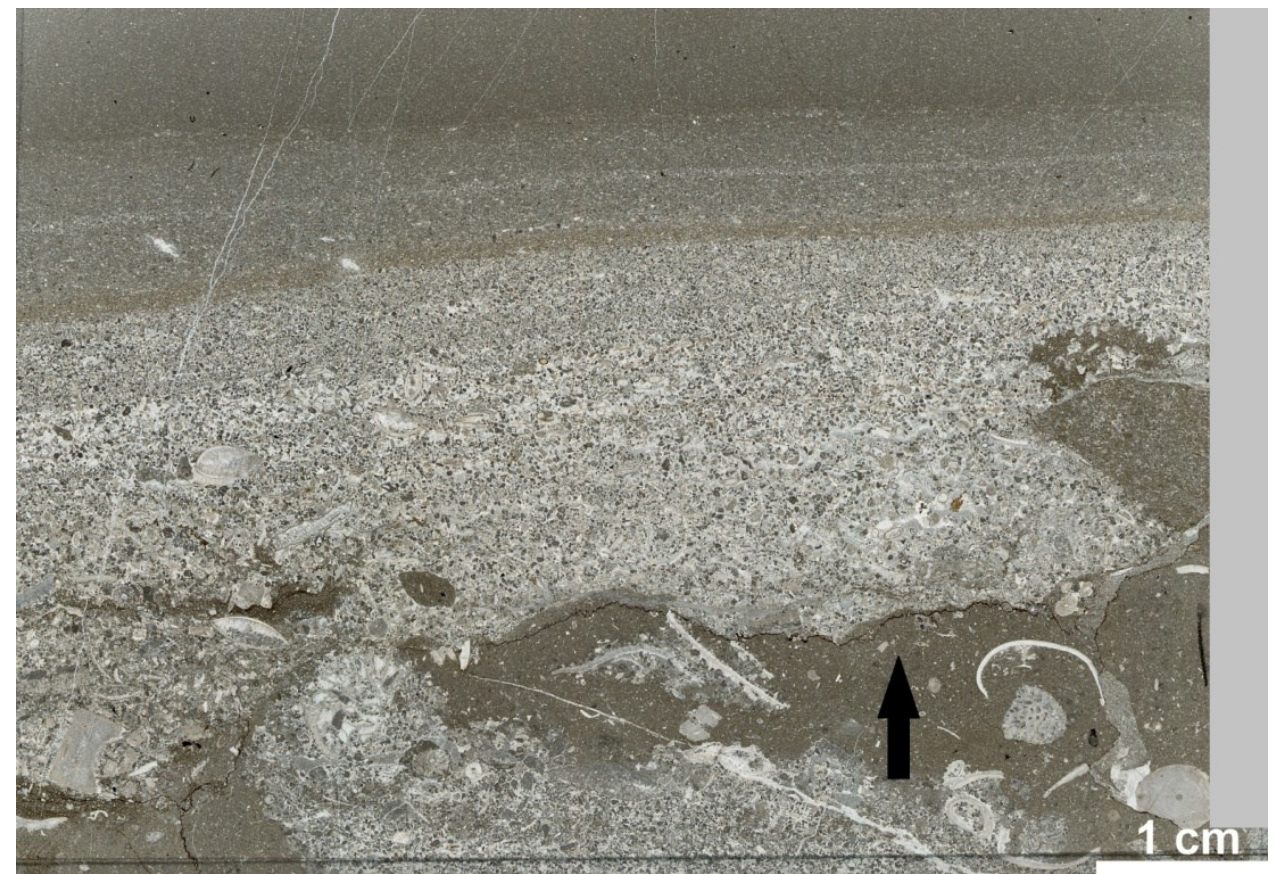

Fot. 3. Pelbiomicrosparites: grained layer with rugged erosional base, stylolites (black arrow) and lamination at the top. Grading is poorly developed within the abundant brachiopod-crinoid debris. The Wietrznia quarry, thin section 39. Fot. A. Vierek.

On the tops of several layers, low-angle cross-lamination or hummocky cross-stratification (HCS) is a characteristic feature (Fot. 2, 3), and indicates a high current regime paired with a combination of unidirectional and oscillatory flow during deposition (e.g., [12]-[15]). At quieter and greater water depths, HCS becomes less distinct and is replaced by parallel laminations that may indicate unidirectional flows. These features are indicative of the transitional tempestites [4]-[5]. Distal tempestites become thinner, finer, rarer, and better preserved, as well as mud-dominated. The bases 
are sharp, plane, and lack basal lags. The tops of sufficiently thick tempestites are burrowed and bioturbated (Fot. 5). In distal zones, with thin tempestites and rare reworking by successive storms, burrowing can markedly overprint or completely obscure storm event stratification. Strong bioturbation indicates breaks in storm activity.

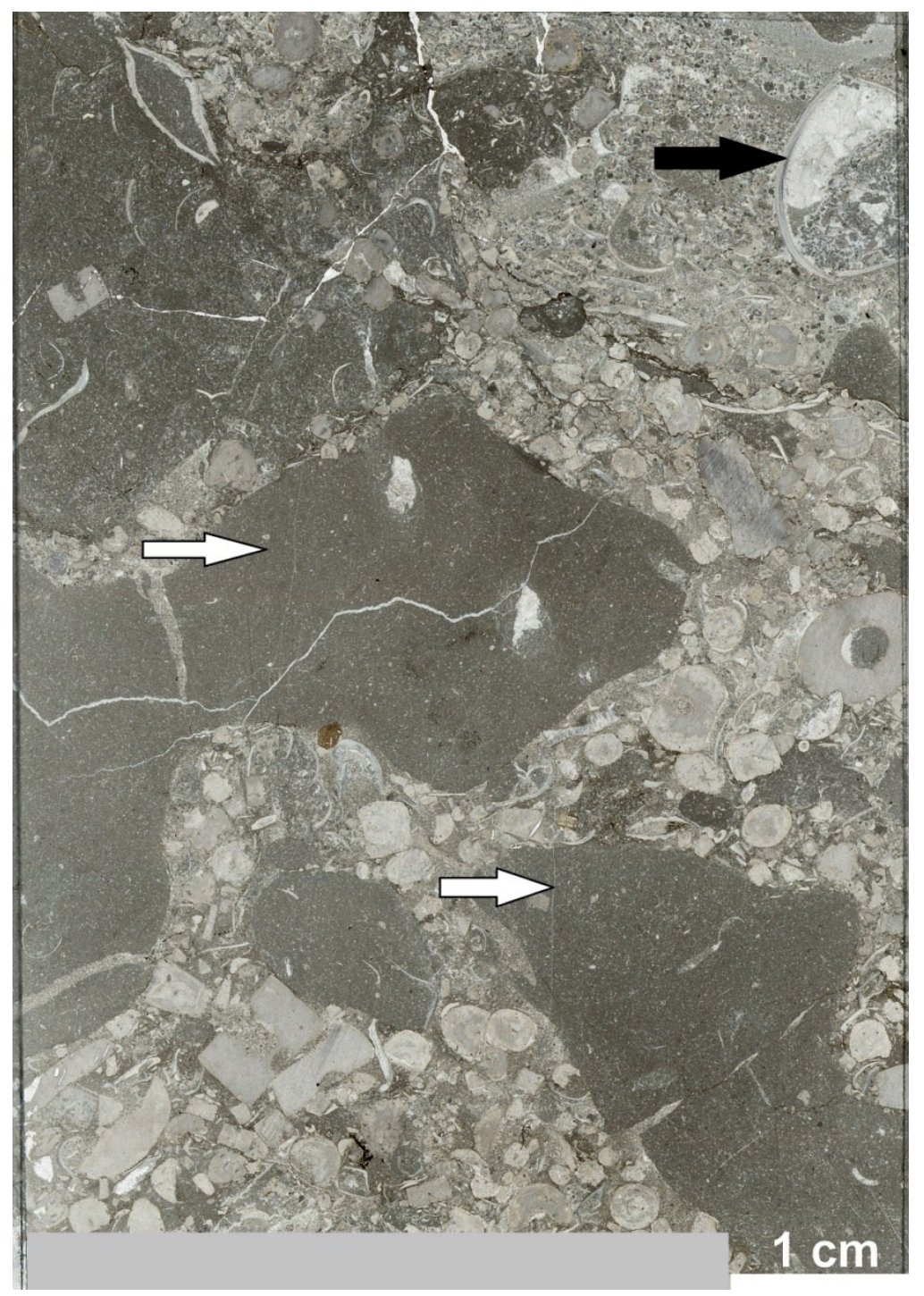

Fot. 4. Intrabiopelspar(rud)ites with irregular intraclasts (white arrows) and numerous crinoid bioclasts. Geopetal structure (black arrow) in the upper right part of the photo. The Wietrznia quarry, thin section $\mathrm{Wg}$ I/92. Fot. A. Vierek.

The next features of tempestites are milimeter- to decimeter- sized micritic intraclasts may indicate redeposition of storm-derived material (Fot. 4). The intraclasts are characterized by various shape, size and roundness: from irregular, chiefly subangular in shape to tabular and highly discoidal, elongated and flattened intraclasts build flat-pebble conglomerates (Fot. 6). The intraclasts are matrix-supported to clast-supported and poorly- to moderately sorted. The flat pebbles are oriented (sub)horizontally or randomly-oriented, steeply inclined or even vertically stacked edge-to-edge intraclasts (Fot. 6). This edgewise (i.e. sub-vertically oriented) intraclast conglomerate was formed by exceptionally intense, storm-generated combined flows. The intraclasts have different components and textures. Many intraclasts are composed of micrite or bioclastic (Fot. 6). Locally, distinctly laminated and bioturbated clasts are embedded in the biosparite matrix (Fot. 5). 


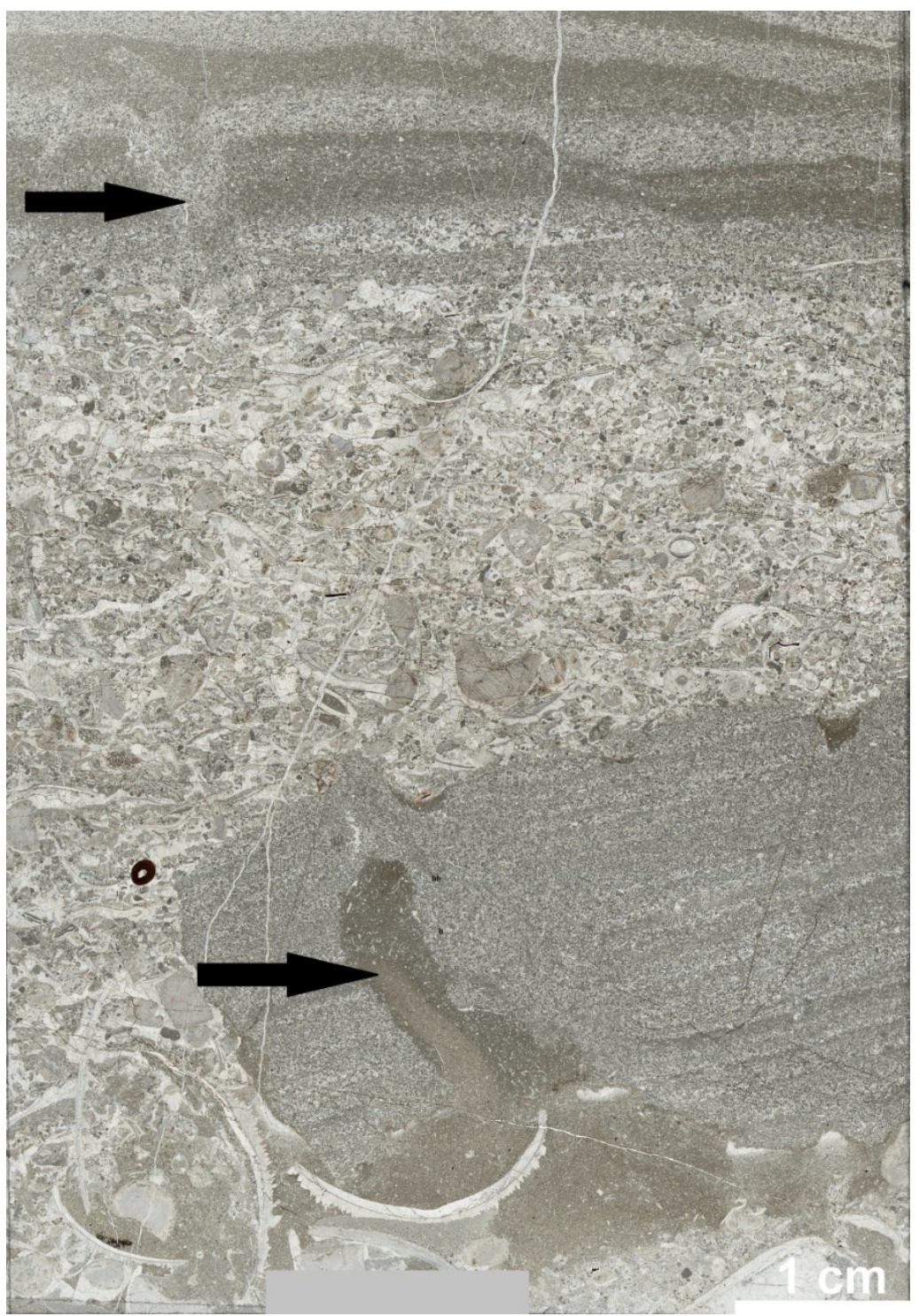

Fot. 5. Intrabiopelsapr(rud)ites of the flat pebble conglomerates with wave lamination at the top (bioturbation - black arrow); lower part of photomicrograph - intraclast with horizontal lamination disturbed by bioturbation (black arrow) The Wietrznia quarry, thin section E52. Fot. A. Vierek.

It is likely indicates frequent, recurrent storm events. The pre-existing thick tempestites were truncated and/or thin tempestites were completely reworked by subsequent storms [5]. The laminated intraclasts in proximal tempestites resulting from reworking of laminated and bioturbated beds underlying the storm beds. 


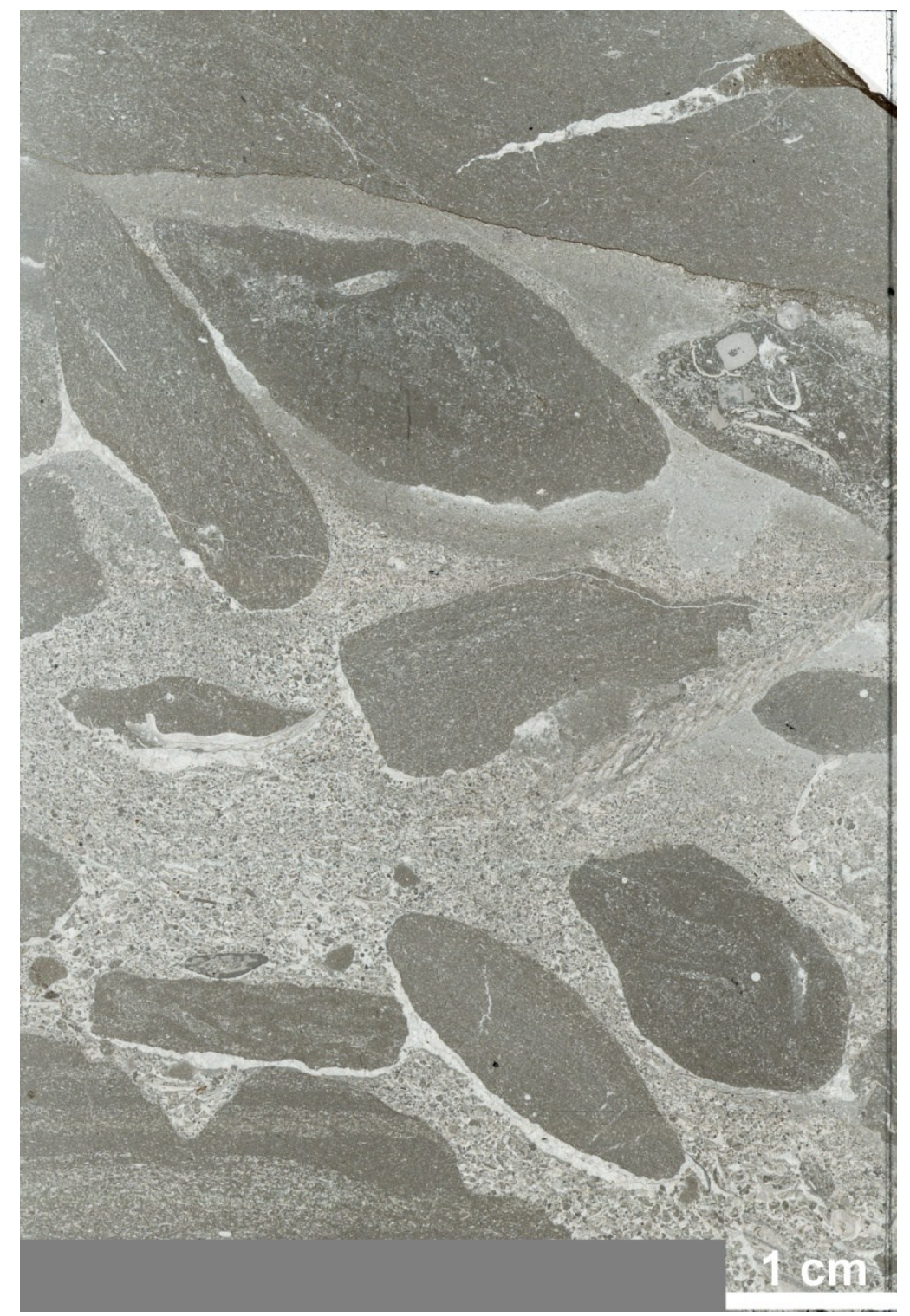

Fot. 6. Flat pebble conglomerates with matrix-supported fabric and both (sub)horizontal and edgewise clast orientations; note micritic and bioclastic intraclasts. The Wietrznia quarry, thin section 25. Fot. A. Vierek.

Skeletal concentrations are common features of many storm beds. Common fossil groups contributing to the formation of storm-related skeletal concentrations are brachiopods and crinoids (Fots. 1-5). In additional, shell beds (coquinas) are common. The characteristic features of the bioclastic storm layers are unstable position (convex-down) of shell [12]. It is a short-term effect of the strong waves wash and rapid deposition in the depressions on the bottom.

The stromatoporoid-coral Dyminy Reef located in the central part of the Kielce region was the source material whose erosion products are coarse-grained proximal tempestites in the Wietrznia quarry. Many dendroid and tabular stromatoporoids, corals, crinoids, brachiopods, bryozoans and trilobites occurs (bioclasts from fore-reef settings, Fot. 7). 


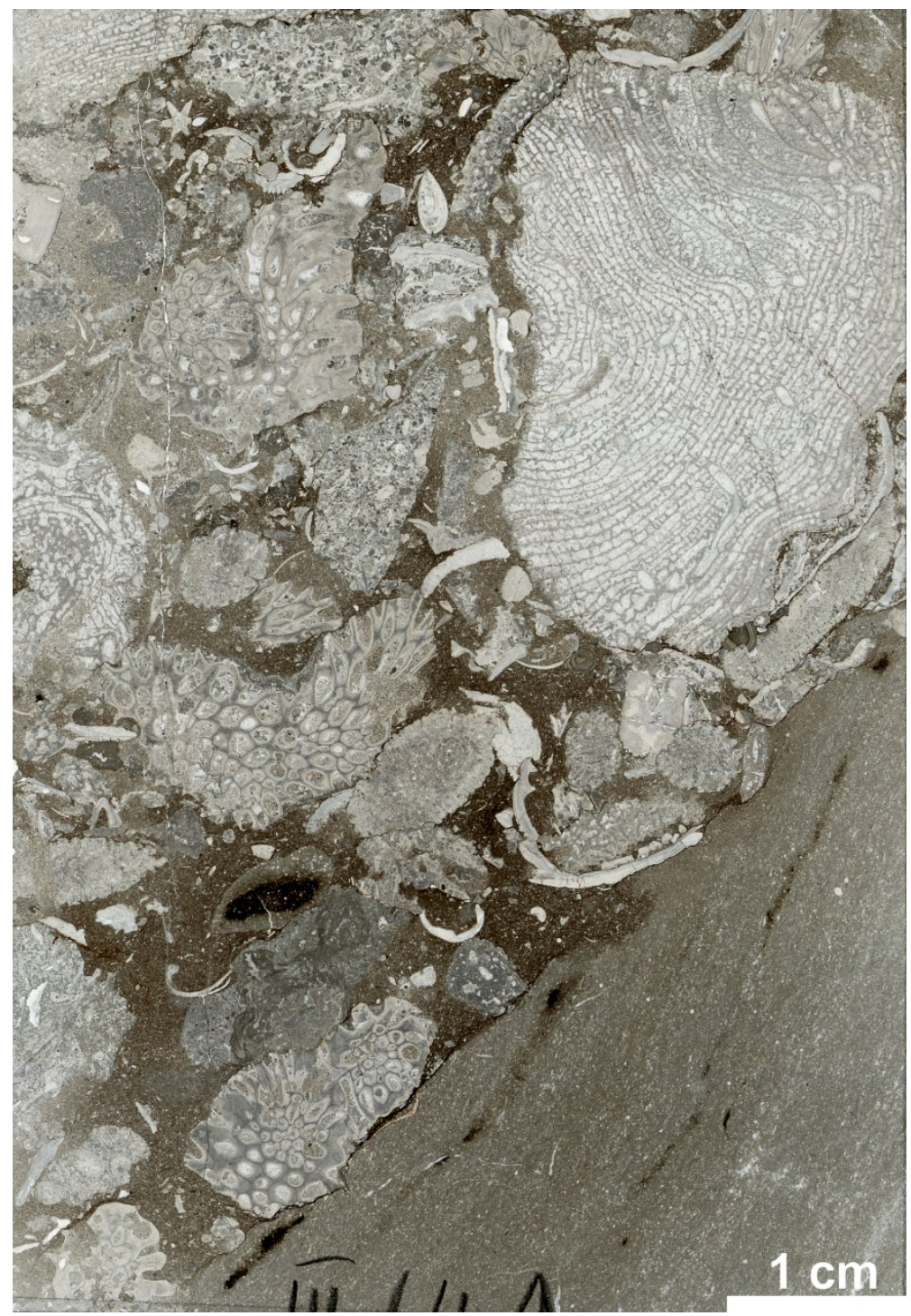

Fot. 7. Limestone reef breccias, biosparudites with high amounts of reef derived biota: stromatoporoids, corals, bryozoans, trilobites. The Wietrznia quarry, thin section III/4. Fot. A. Vierek.

The geopetal infillings in fossils suggest rapid burial during storm events [3] (Fot. 4). According to Abbassi [16], trace fossils such as Chondrites reflect moderate to relatively low energy in an intertidal to shallow subtidal zone below the fair-weather wave base, but not below the storm-wave base.

To sum up, a lower-energy and deeper waters are highlighted by a relative lesser biotic diversity and fine-grained nature of the sediment. Furthermore, abundant peloids are typical of such a low- to medium-energy environment. During transition into high-energy conditions, the number and diversity of bioclasts increases and the nature of the sediments changes to coarse-grained (intraclasts start to appear that compose both conglomerates and breccias; Fot. 3 and Fots. 1, 4).

\section{CONCLUSIONS}

The microfacies described both lithological and micropaleontological features of rocks in high microscope scale aggrandizement. In carbonate sediments microfacies studies provide an invaluable source of information on the depositional constrains and environmental controls of carbonates, as well as on the properties of rocks. However, the microfacies study is always complement fieldworks. The facies analysis of ancient storm deposits requires the integration of lithofacies (lithological features of rocks), biofacies (skeletal concentrations and trace fossilis) and microfacies. 
Only then we can say with full recognition of the probability of ancient tempestites. The more that, storm deposits are physically similar to deposits from other genetically unrelated processes, such as turbidity.

\section{References}

[1] D.V. Ager, Palaeogeography Palaeoecology Palaeoclimatology 15 (1974): 83-93

[2] T. Aigner, Lecture Notes in Earth Sciences, 3 (1985): 174 pp

[3] E. Flügel, Springer, Berlin (2004), 976 pp

[4] A. Vierek, Geological Quarterly, 51 (2007): 307-318

[5] A. Vierek, G. Racki, Palaeogeography Palaeoecology Palaeoclimatology, 312 (2011): 1-23

[6] R.L. Folk, Ammerican Association Petroleum Geologist Bulletin, 43 (1962): 62-84

[7] V.P. Wright, Sedimentary Geology, 76 (1992); 177-185

[8] M. Szulczewski, Przegląd Geologiczny, 25 (1977): 428-432

[9] G. Racki, Acta Paleontologica Polonica, 37 (1993): 87-182

[10] A. Vierek, Geologos, 19 (2013): 257-272

[11] A. Vierek, Geologos, 16 (2010): 153-168

[12] R.D. Kreisa, Journal of Sedimentary Petrology, 51 (1981): 823-848

[13] R.H. Dott, J. Bourgeois, Geological Society of Ammerican Bulletin, 93 (1982): 663-680

[14] W.L. Duke, Sedimentology, 32 (1985): 167-194

[15] J.M. Molina, P.A. Ruiz-Ortiz, J.A. Vera, Sedimentary Geology, 109 (1997): 95-109

[16] N. Abbassi, Iranian Journal of Science \& Technology, 31 (2007): 23-33 